\title{
Unge revmatikere får hjelp til å takle voksenlivet
}

Kronisk syke ungdommer kan få kultursjokk når de overføres fra barneavdeling til voksenavdeling. For å gjøre ovegangen lettere, er det ved St. Olavs hospital innført et standardisert pasientforløp for unge revmatikere.

\section{Forfattere}

\section{Karen Folvik}

Sykepleier

Institutt for samfunnsmedisin og sykepleie, Norges teknisk-naturvitenskapelige universitet

Kjersti Grønning

Førsteamanuensis

Institutt for samfunnsmedisin og sykepleie, Norges teknisk-naturvitenskapelige universitet

Informasjon Intervju Kronisksykdom Ungdom

Sykepleien 2019 107(76634)(e-76634)

DOI: https://doi.org/10.4220/Sykepleiens.2019.76634

\section{Hovedbudskap}

Tilpasset informasjon og relasjonsbygging er viktig for å veilede unge pasienter med revmatisk sykdom til å bli selvstendige voksne. Et standardisert pasientforløp, kalt ungdomsforløpet, med tilhørende sjekkliste for informasjon og veiledning bidrar til at disse pasientene opplever kontinuitet, tillit og trygghet når de har behov for oppfølging i spesialisthelsetjenesten. 
Fagartikkelen er skrevet med utgangspunkt i en bacheloroppgave i sykepleie (1). Vi undersøkte sykepleiernes erfaringer om hvordan overgangen fra barn til voksenavdeling fungerte for unge voksne mellom 16-25 år ved revmatologisk avdeling, St. Olavs hospital. I tillegg etterspurte vi hva sykepleierne legger vekt på i møtene med de unge pasientene.

«Du vekker'æ sjæl og kjenner'æ helt aleine ... Du kjenner at nå, det er nå du må stå for det du gjør sjæl ...» (2, s. 17)

Teksten til Trond-Viggo Torgersen fra 1981 treffer trolig godt det vår tids ungdom føler om overgangen til voksenlivet. Alle har vært igjennom det.

Kroppen er i stadig endring, ungdommen får nye følelser de ikke har hatt før, og sosiale samhandlinger blir mer kompliserte. I tillegg til å finne ut hvem man er skal man løsrive seg fra foreldre og bli mer selvstendig. Mange unge kan føle på at de befinner seg midt i en livskrise (3).

\section{Særlige utfordringer}

For ungdommer med revmatiske sykdommer som artritt (leddbetennelse), vaskulitt (betennelse i blodårer) og bindevevssykdommer kan dette by på særlige utfordringer. I tillegg til å mestre utviklingen til et voksent liv, skal de også lære seg å leve med sin kroniske sykdom og mestre utfordringer knyttet til smerter og fatigue (3). Sykdommen kan påvirke skolen, sosiale relasjoner, seksualliv og fritid. Hvem man er og hvem man vil være stemmer kanskje ikke overens, livsperioden kan innebære en større identitetskrise enn hos friske jevnaldrende (4). Håp, lengsler, forventninger og tanker påvirkes av betraktningen om at man har begrensninger. Begrensninger de andre ungdommene i klassen ikke har. 
Østlie og Aaslands (5) studie fra 2011 viste at hele 45 prosent av ungdommer med revmatisk sykdom mente de ikke hadde fått tilstrekkelig informasjon om diagnose, behandling og hvordan de skal mestre hverdagen. Ungdommene rapporterte også at de ikke hadde vært deltakende i beslutninger angående egen helse. Flere andre studier $(6,7)$ viser at ungdom med kroniske sykdommer har behov for tilrettelagt informasjon.

\section{三 «Det er minst like viktig å skape tillit og gode relasjoner som å sette injeksjoner og skrive ut resepter.»}

Informasjon og veiledning fra helsepersonell og pårørende kan føre til at ungdommer med revmatiske sykdommer får økt medvirkning og ansvarliggjøring og det kan bidra til at de får bedre forutsetninger for å kunne bli selvstendige og uavhengige (5). I denne sammenhengen er det viktig at helsepersonell er bevisst på at det er minst like viktig å skape tillit og gode relasjoner som å sette injeksjoner og skrive ut resepter (4).

\section{Kan få kultursjokk}

«En dag er det slutt, nå står du der helt aleine ...» (2).

Fra den dagen ungdommen fyller 18 år overføres de fra alt og alle de kjenner på barneavdelingen til nye mennesker, krav og forventninger ved voksenavdelingen. Denne transisjonen (8) kan bli et kultursjokk for ungdommene og deres pårørende (9).

\section{Hva er transisjon?}

Transisjon betyr overgang, og defineres i denne sammenhengen som en målrettet og planlagt prosess som adresserer de unge voksnes behov ved overgang fra barne- til voksenavdelingen. 
Kilde: (8).

Studien til Aasland og Østlie (5) viste at 70,6 prosent av pasientene ikke var forberedt på overføringen fra pediatrisk- til voksen avdeling. En annen studie (10) har avdekket at en stor andel av de unge pasientene følte at de ble plassert i voksenavdelingen uten spesiell forberedelse.

En litteraturstudie viste at manglende tilbud for oppfølging kan resultere i at de unge voksne pasientene ikke følger helsefaglige råd, de dropper å møte til kontroller, de utvikler risikoatferd når det gjelder egen helse, og de kan dermed få en forverret sykdomstilstand med økt risiko for komplikasjoner (11). Flere studier bekrefter at et strukturert overgangsprogram for unge med kronisk sykdom er viktig for å unngå de uønskede konsekvensene (11, 12).

\section{Anbefaling fra forbund}

The European League Against Rheumatism (EULAR) har utarbeidet anbefalinger for overgangen fra barnetil voksen revmatologisk avdeling. Målet er at unge voksne skal ha tilgang til koordinert behandling og transisjon med gjennomgående høy kvalitet. Dette innebærer et godt samarbeid mellom helsevesenet, pasienten og deres pårørende. Overgangen bør være fokusert rundt ungdommens individuelle behov og det bør være et eget team som jobber med transisjonen og fungerer som koordinatorer (13). Sykepleieren skal tilrettelegge for at pasienten får styrket sin egenomsorg (14). EULAR viser til at gode overganger fra barne- til voksen revmatologisk avdeling fører til bedre sykdomsforståelse, økt mestring, bedre compliance (i hvilken grad pasienten følger legens råd) og økt tilfredshet blant de unge pasientene (13).

\section{Standardisert forløp}


Revmatologisk avdeling ved St. Olav hospital har satt EULARs anbefalinger ut i praksis og utarbeidet et standardisert pasientforløp, også kalt ungdomsforløpet, for unge voksne mellom 16-25 år. Avdelingen har satt overgangsomsorg i system og har et tett samarbeid med barneavdeling, sykepleier og koordinator, pasienten selv og deres pårørende. Hensikten med denne studien er derfor å undersøke hvordan sykepleierne mener forløpet fungerer og hva de vektlegger i møte med ungdommen.

\section{Metode}

For å undersøke hva sykepleierne vektlegger i møte med ungdom og hvilken innvirkning forløpet har hatt ble det gjennomført tre semistrukturerte intervjuer ved revmatologisk avdeling, St.Olavs hospital i mars 2018. Informantene var alle sykepleiere med flere års erfaring med sykepleie til ungdom.

\section{Resultater}

Analysen av intervjuene viste at alle informantene var enige om at ungdomsforløpet har gjort det enklere å veilede de unge pasientene til selvstendighet.

Sykepleierne gjorde dette ved å tilpasse informasjon til pasientene, skape en god relasjon mellom pasienter og sykepleiere og ved å ha en kontinuitet i behandlingen. Resultatene fra analysen ble sammenfattet til tre hovedkategorier; å veilede til selvstendighet, å tilrettelegge informasjon og ungdomsforløpet.

\section{$\AA ̊$ veilede til selvstendighet}

Informantene fortalte at ungdommenes foreldre og den rollen de hadde på barneavdelingen kontra på voksenavdelingen kunne være en utfordring $\mathrm{i}$ konsultasjonene. Det var et stort spenn i grad av selvstendighet og uavhengighet blant pasientene, og det var sjelden at de nylig overflyttede ungdommene kom alene ved første møte. Sykepleierne var opptatt av å skape tillit. 
En informant opplevde at det å få tillit fra foreldrene og hjelpe foreldrene til å slippe taket på behandlingen, var den største utfordringen.

Flere av informantene hadde erfart at det var en brå overgang for ungdommene når de skulle komme uten foreldrene fordi det hadde ikke vært mye informasjon om dette på barneavdelingen, selv om pasientene nærmet seg 18 år. Informantene uttrykte at den mest utfordrende perioden var da pasientene var medisinsk stabile og det var få kontroller. Ungdommene fikk ikke trent så mye på å være uavhengige i den perioden. Det var foreldrene som hadde kontroll på pasientens sykdomshistorikk og forløp. Informantene forklarte at de forsøkte å motivere pasienten til å komme uten foreldrene ved neste kontroll.

\section{三 «Det var foreldrene som hadde kontroll på pasientens sykdomshistorikk.»}

En informant vektla særlig at de skal snakke med, og ikke om ungdommen. Vedkommende fortalte at de unge ønsker å være en viktig aktør i samtalene og få mer ansvar, selv om foreldrene er til stede.

Informanten fortalte videre at foreldre kunne supplere og komme med innspill, men pasienten var den sykepleieren henvendte seg til.

Informantene fortalte at de tilbyr et «hilse-på-møte» før første konsultasjon. Møtet inneholder omvisning på avdelingen og de unge pasientene får treffe helsepersonellet de skal forholde seg til i ungdomsforløpet. I tillegg fikk ungdommene mer informasjon om ungdomsforløpet for å gjøre dem tryggere på situasjonen. Informantene fortalte også at ungdommene fikk tilbud om å delta på lærings- og mestringskurs med jevnaldrende og at dette hadde fungert godt. 
En informant sa: «Vi forsøker å lære dem til å bli mer selvstendig og hjelpe dem til en forståelse om hvorfor dette er viktig».

Å bidra til at unge pasienter blir selvstendig er essensielt for å fremme helse og forebygge forverring av sykdommen (5). Forskning viser at denne pasientgruppen trenger ekstra støtte for å oppnå selvstendighet og at det å veilede ungdom til ansvarlighet rundt egen sykdomssituasjon er fundamentalt. Det viser seg at gode medisinske rutiner ikke nødvendigvis blir bedre med alderen og en avgjørende faktor kan være manglende mulighet for medvirkning, helt fra starten av tenårene (15).

En annen studie (5) viser at medvirkning i behandlingen er til dels mangelfull. Vår studie viser imidlertid at sykepleierne er opptatt av å forme selvstendig ungdom, men at det er uvisst hvor mye trening ungdommene får i forkant av transisjonen. Ungdommene er forskjellige, og for mange er overgangen fra å være barn til å bli et selvstendig voksent menneske, selv etter innføringen av forløpet, fremdeles for brå.

Informantene fortalte at de fokuserer mye på å gi ungdommene redskaper for å kunne bli ansvarlige voksne mennesker og involvere de aktivt i avgjørelser om egen helse og behandling. Relasjons- og tillitsbygging er vesentlige faktorer, hvor tiltak som «hilse-på-møte» og muligheten til å møte samme sykepleier kan føre til at ungdommene får en følelse av forutsigbarhet. Det er god grunn til å tro at grunnlaget for et solid tillitsforhold dermed er lagt $(9,12)$. 
Muligheten til å delta på lærings- og mestringskurs var også noe sykepleierne hadde gode erfaringer med.

Kursene var utarbeidet sammen med de unge. Stinson og medarbeidere (6) viser i sin undersøkelse at ungdom opplever større forståelse gjennom sosial støtte og ved å møte andre i samme situasjon, og forståelse er ifølge Stinson en viktig grunnpilar på veien mot uavhengighet.

\section{$\AA$ A tilrettelegge informasjon}

Informantene beskrev at de informerte om sykdommen, behandling, virkning og bivirkning av medisiner, men at de også vektla det å være ung med de utfordringer som hører med til livet enten man er frisk eller har en kronisk sykdom.

En informant uttrykte: «Vi bruker mye av tiden på det ungdommene selv lurer på og har på hjertet. Det å være ung står mye i fokus».

Tema sykepleierne tok opp i konsultasjonene dreide seg om seksualitet og prevensjon, hvordan sykdommen kan påvirke seksuallivet med tanke på fatigue og fysiske begrensninger. Alkoholbruk ble også tatt opp da enkelte av medisinene krever forsiktighet med tanke på leververdier. Informantene fortalte at alkoholbruk kunne være en utfordring med den aktuelle aldersgruppen i tillegg til compliance. Medisiner ble glemt, som muligens handlet om mangel på rutiner, bivirkninger som kanskje ikke var forenelige med ungdommens hverdagsliv, og smerter/ubehag ved injeksjoner.

En annen informant sa: «Aldersgruppen har vanskelig for å forstå hvordan ting man gjør nå kan få konsekvenser i fremtiden. Da forsøker vi å få de til å forstå alvorlighetsgraden av hva som kan skje og gjentar informasjonen, igjen og igjen». 
Ved spørsmålet til informantene, fra intervjuguiden, om de hadde skriftlig informasjon som var tilpasset aldersgruppen fortalte informantene at de hadde egne brosjyrer om hvordan være ung med revmatisk sykdom. Annen informasjon om eksempelvis medikamenter var standard for alle pasienter, den var ikke spesielt tilpasset aldersgruppen.

Forskning fremhever viktigheten av at helsepersonell bruker informasjon og veiledning som redskaper for å oppnå selvstendighet hos ungdommene (7). For at den unge skal leve et mest mulig selvstendig liv og samtidig beherske det å skulle bli voksen, er det behov for god informasjon, råd og veiledning fra helsepersonell basert på ungdommenes egne forutsetninger. Manglende oppfølging vil kunne få store følger for pasientens liv og helse (5).

Denne studien fant at compliance mht. medisiner kunne være en utfordring blant ungdommene, noe som støttes av annen forskning (15) som fant en til to tapte doser per uke blant ungdom. I den studien ble det avdekket flere grunner til at ungdom ikke fulgte råd om medikamentbruk. Eksempelvis følte ungdommene seg friske og tenkte det ikke var nødvendig å ta medisiner. Noen får også plagsomme bivirkninger eller opplever smertefulle injeksjoner. Dette er ikke alltid forenelig med livet som ung. Andre ganger kan medisinen bli glemt bort i en hverdag full av fart og spenning $(9,15)$.

Forskning $(5,7)$ viser at ungdom har ekstra behov for informasjon om kombinasjonen medisiner, alkohol og andre rusmidler. Informantene fortalte at de snakket om dette under konsultasjonene. Men det er alltid rom for misforståelser og mistolkninger. Eksempelvis står det i den skriftlige informasjonen om syntetisk medisin at dette ikke er forenelig med alkohol, samtidig ga sykepleierne muntlig informasjon om at pasientene kunne drikke et par enheter i helgen, men burde vise forsiktighet. 


\section{Ungdomsforløpet}

Informantene fortalte at ved implementeringen av ungdomsforløpet ble det utarbeidet en sjekkliste for hvilken informasjon som ble gitt og som skulle sikre at ungdommen ble spurt om temaer knyttet til ungdomstiden. Sykepleierne mente at sjekklisten skapte kontinuitet i behandlingen, men at kontinuiteten var avhengig av at sjekklisten ble tatt i bruk på et tidlig stadium, helst allerede på barneavdelingen, før pasientene sluttet der.

To av informantene mente at sjekklisten ikke fungerte helt optimalt ennå, fordi de hadde erfart at barneavdelingen ikke brukte den. Ellers fortalte informantene om flere faktorer ved ungdomsforløpet som hadde vært svært gunstig for å gjøre overgangen mer glidende og enklere for ungdommen, for eksempel muligheten de har til å ringe kjente sykepleiere ved behov. Pasientene kan ringe en egen «ungdomstelefon» mellom kl. 8-16 i ukedager, og slippe den vanlige telefonkøen. Sykepleierne mente tiltaket hadde mye å si for relasjons- og tillitsbyggingen mellom sykepleier og pasient.

En av informantene sa: «Det skal være en lav terskel på å få tak i oss. Det er et godt tegn at de ringer, det viser tillit».

En annen viktig faktor som ble nevnt av informantene var at trygghetsfølelsen og kontinuiteten som kom i forløpet, hadde økt, spesielt etter det ble bestemt at pasientene skulle få egne ungdomskoordinatorer. 
Informantene beskrev at ungdommene ble godt kjent med sykepleierne og de slapp å forholde seg til nye mennesker ved hvert besøk. Informantene mente også at dette muligens gjorde det litt enklere for ungdommene å komme alene, fordi de visste hvem de skulle møte og hva de gikk til. Generelt mente alle informantene at ungdomsforløpet hadde gjort det enklere å følge opp ungdommen og skape en god relasjon.

Informanten sa: «Vi blir kjent med hverandre på en helt annen måte. Det tar ofte litt tid før ungdommen åpner seg og våger å ta opp ting. Kanskje våger de ikke første gangen, men tredje gangen vi møtes kjenner de meg godt nok og er trygg nok på meg til å snakke om eksempelvis alkohol eller sex».

\section{Konklusjon}

Resultatene viser at sykepleiere ved revmatologisk avdeling vektlegger det å veilede unge til å bli selvstendige voksne mennesker gjennom tilpasset informasjon og relasjonsbygging i konsultasjonene. Resultatene viser også at sykepleierne mener ungdomsforløpet har bidratt til kontinuitet, tillit og trygghet gjennom mulighet til å møte samme sykepleier, både på telefon og i konsultasjoner. I tillegg viser funn at implementering av sjekkliste for informasjon og veiledning har gjort det enklere å informere om tema utenom sykdommen.

Vi ønsker spesielt å takke sykepleier Morten Andersen ved Revmatologisk avdeling, St. Olavs hospital for gode innspill i forbindelse med gjennomføring av denne studien.

\section{Referanser}


1. Folvik KB. Mot selvstendighet i

transisjonsprosessen. (Bacheloroppgave.) Trondheim:

Norges teknisk-naturvitenskapelige universitet; 2018.

Tilgjengelig fra:

https://app.cristin.no/projects/show.jsf?

id=589432 (nedlastet: 04.04.2019).

2. Refvik S. Alle tiders sangbok. 4. utg. Oslo: Norsk noteservice; 2013.

3. Fjerstad E. Frisk og kronisk syk: et psykologisk perspektiv på kronisk sykdom. Oslo: Gyldendal Akademisk; 2010.

4. Ekeland TJ. Psykologi for sosial- og helsefag. 2 utg. Oslo: Cappelen Damm Akademisk; 2010.

5. Østlie I, Aasland A. Hvordan forberede unge mennesker med juvenil idiopatisk artritt på voksenlivet? Sykepleien forskning. 2011;6(3):214-21.

6. Lipstein EA, Muething KA, Dodds CM, Britto MT. «I'm the one taking it»: adolescent participation in chronic disease treatment decisions. J Adolesc Health. 2013;53(2):253-9.

7. Stinson JN, Stevens TP, Kagan S, Duffy CM, Huber A. Malleson P, et. al. Asking the experts: exploring the self- management needs of adolescents with arthritis. Arthritis Rheum. 2008;15;59(1):65-72.

8. Kooyman LM, Hjørnevik JE, Hegg RM. Ungdom med tarmsykdom må forberedes på overgangen til voksenavdeling. Sykepleien 2019 106(75571) (e75571). Tilgjengelig fra:

https://sykepleien.no/forskning/2019/02/ungdom-medtarmsykdom-ma-forberedes-pa-overgangen-tilvoksenavdeling. (nedlastet 02.04.2019).

9. Grønseth R, Markestad T, Gaust D. Pediatri og pediatrisk sykepleie. 3. Utg. Bergen: Fagbokforlaget; 2011. 
10. Cruikshank M, Foster H, Stewart J, Davidson JE, Rapley T. Transitional care in clinical networks for young people with juvenile idiopathic arthritis: current situation and challenges. Clin Rheumatol.

2015;35:893-9.

11. Crowley R, Wolfe I, Lock K, McKee M.

Improving the transition between pediatric and adult healthcare: a systematic review. Arch Dis Child. 2011;96(6):548-53.

12. McDonagh JE, Southwood TR, Shaw, KL. The impact of a coordinated transitional care programme on adolescents with juvenile idiopathic arhritis. Rheumatology (Oxford). 2007;46(1):161-8.

13. Foster HE, Clemente D, Leon L, McDonagh JE, Kamphuis S, Berggren K, et. al. EULAR/PReS standards and recommendations for the transitional care of young people with juvenile-onset rheumatic diseases. Ann Rheum Dis. 2017;76(4):639-46.

14. Renpenning KM, Taylor SG, red. Self- care theory in nursing: selected papers of Dorothea Orem. New York: Springer; 2003.

15. Lawson, EF, Aimee OH, Applebaum MA, Yelin EH, Megumi JO, Scheven EV. Self- management skills in adolescents with chronic rheumatic diseases: A cross- sectional survey. Pediater Rheumatol Online J. 2011; 9:35. 